\title{
Bazzania Gray (Lepidoziaceae, Marchantiophyta) in Central Java, Indonesia
}

\author{
LILIH KHOTIMPERWATI ${ }^{1.2, \bullet}$, RINA SRI KASIAMDARI ${ }^{2, \bullet \bullet}$, SANTOSA $^{2}$, BUDI SETIADI DARYONO $^{2}$ \\ ${ }^{1}$ Department of Biology, Faculty of Sciences and Mathematics, Universitas Diponegoro. Jl. Prof. Soedharto, Tembalang, Semarang 50275, Central Java, \\ Indonesia. Tel./fax.: +62-024-76480923, "email: lilih@undip.ac.id \\ ${ }^{2}$ Department of Tropical Biology, Faculty of Biology, Universitas Gadjah Mada. Jl. Teknika Selatan, Sekip Utara, Sleman 55281, Yogyakarta, Indonesia. \\ Tel./fax.: +62-274-546860, ${ }^{*}$ email: rkasiamdari@ugm.ac.id
}

Manuscript received: 20 February 2018. Revision accepted: 21 April 2018.

\begin{abstract}
Khotimperwati L, Kasiamdari RS, Santosa, Daryono BS. 2018. Bazzania Gray (Lepidoziaceae, Marchantiophyta) in Central Java, Indonesia. Biodiversitas 19: 875-887. Bazzania has the largest species of the family Lepidoziaceae (Marchantiophyta). This genus is abundant in the moist montane forest. Diversity of Bazzania in Java insufficiently reported, especially publications about its diversity in Central Java have never been reported. Therefore this study aimed to explore the diversity of Bazzania in Central Java. Studies of the Bazzania were based on the specimens collected from three mountains in Central Java, i.e. Mt. Lawu, Mt. Ungaran and Mt. Slamet. The observation in the laboratory was done based on the morphological and anatomical feature of the stem, lateral leaf, underleaves (amphigastria) and microphyll. Identification of the species used the existing literature that contains key identification, description or illustration of the Bazzania. Eleven species of Bazzania were identified from Central Java, namely Bazzania calcarata, B. japonica, B. javanica, B. pectinata, B. praerupta, B. serpentina, B. spiralis, B. tridens, B. fauriana, B. perfalcata and B. succulenta. Three new record species, namely $B$. fauriana, B. perfalcata and B. succulenta are reported for Java. This result is the first report of Bazzania in part of Central Java.
\end{abstract}

Keywords: Bazzania, Marchantiophyta, diversity, Central Java, Indonesia

\section{INTRODUCTION}

Bazzania Gray is one of the leafy liverworts in the family Lepidoziaceae, subfamily Bazzanioidea. Bazzania can be differentiated from the other genera based on morphological features such as terminal branch pseudodichotomous (like a Y-shaped resembles dichotomous branch), long flagelliform branch arising from underleaves and minute leaves resembling scales (microphyll), lateral leaves incubously on the stem, 2-3 toothed leaf apex, a large ventral leaf (amphigastrium= underleaf) (Gradstein et al. 2001; Meagher 2006; Cheah and Yong 2016; Gradstein 2017). Identification at the species level in the genus often has difficulty, because of its high variability of morphological characters. Variations of morphological characters are affected by the environment factors, especially microclimate, such as light intensity, humidity and ambient temperature (BerneckerLucking 1999; Zhou et al. 2012; Gradstein 2017).

The habitat of Bazzania in the wild population is commonly on the bark, moist soil, and rock covered with hummus. Bazzania grows like a carpet at the bottom of the tree as well as thick turfs on trees and branches from the canopy. Bazzania can be found from the lowlands to the foggy in the high mountains at altitude $1300 \mathrm{~m}$ asl., abundant in the forests in the moist zones of Montana (Kitagawa 1977; Gradstein et al. 2001).

Bazzania is the largest genus in Lepidoziaceae with about 100 accepted names of species in the worldwide
(Gradstein et al. 2001; Gradstein 2017). The number of species is predominantly in the tropics and southern hemisphere. Several data about the diversity of Bazzania in Indonesia have been recorded. In Borneo, Bazzania is represented by 14 species (Menzel 1988), seven species from Celebes (Gradstein et al. 2005), and 40 species from Sumatra (Schiftner 1898; Evans 1933; Meijer 1960; Kitagawa 1967; Sari 2015; Lestari and Ariyanti 2017). Recent explorations in Sumatra show five new recorded of Bazzania species, namely Bazzania horiidula, $B$. oshimensis, B. adnexa, B. angustifolia f. paupera and $B$. fauriana. The three last species (B. adnexa, $B$. angustifolia f. paupera and B. fauriana) are also new records of the region of Malesiana (Lestari and Ariyanti 2017).

Central Java has many mountains as the habitat of Bazzania. However, the research and exploration of liverworts especially Bazzania are very limited. Meijer (1960) noted that in Java, there were 26 species and almost of species collected from West Java, only one species has reported from Central Java (Mt. Lawu), namely $B$. tridens. Soderstrom et al. (2010) made a checklist of the hornworts and liverworts of Java, there were 34 species of Bazzania. Meanwhile, according to Gradstein (2011) in the guide to the liverworts and hornworts of Java, there are 29 species of Bazzania. The species are $B$. angustisedens, $B$. calcarata, B. commutata, B. densa, B. desciscens, B. erosa, B. fallax, B. fleischeri, B. gedeana, B. grandiretis, $B$. horridula, $B$. indica, $B$. intermedia, $B$. japonica, $B$. javanica, B. linguiformis, B. longicaulis, B. loricata, $B$. 
manillana, B. paradoxa, B. pectinata, B. praerupta, $B$. serpentina, $B$. spiralis, $B$ subtilis, $B$. tridens, $B$. uncigera, $B$. vittata, $B$. zollingeri. Furthermore, information about of species of Bazzania in Central Java has never been reported, so that the research on the diversity of Bazzania in Central Java is necessary to be done. This study is expected to complement the liverworts, especially of Bazzania data in Java.

\section{MATERIALS AND METHODS}

\section{Study area}

Based on the literature, the diversity and distribution of Bazzania in Java, they were distributed at 1.000-2.500 m asl. (Meijer, 1960), or the tropics to the montane zone (Steenis, 1972). Bazzania was collected from three mountains in Central Java (Mt. Lawu, Mt. Ungaran, and Mt. Slamet), the locations represents the distribution of Bazzania in Central Java. The exploration for collecting Bazzania at Mt. Lawu was carried out in May 2015, conducted was primarily in the climbing track of Cemara Kandang, is located at 1910-2576 m asl. 07³9'833"$07^{\circ} 38^{\prime} 21.0^{\prime \prime}$ S $111^{\circ} 11^{\prime} 511^{\prime \prime}-111^{\circ} 11^{\prime} 00.0^{\prime \prime} \quad$ E, with temperature $15.9-22.5^{\circ} \mathrm{C}$, humidity $54.6-91.7 \%$. The exploration for collecting Bazzania at Mt. Ungaran was carried out in May 2015, conducted was primarily at around of mount peak, is located at $2040 \mathrm{~m}$ asl., $07^{\circ} 11^{\prime} 03.0^{\prime \prime S} 110^{\circ} 20^{\prime} 87.9^{\prime \prime} \mathrm{E}$, with temperature 22-23 C, humidity 55.1-74\%. Meanwhile the exploration for collecting Bazzania at Mt. Slamet was carried out in September 2015, conducted was primarily in the climbing track of Baturaden, Purwokerto, is located at 931-1941 m asl., 07 $16^{\prime} 22.5^{\prime \prime}-07^{\circ} 18^{\prime} 17.8^{\prime \prime} \mathrm{S} 109^{\circ} 12^{\prime} 14.1^{\prime \prime}-109^{\circ} 12^{\prime} 38.6^{\prime \prime}$ $\mathrm{E}$, with temperature $18.1-28.2^{\circ} \mathrm{C}$, humidity $50.7-91.8 \%$. (Figure 1).

\section{Sampling collection and identification}

The Bazzania collection at each location was conducted by purposive sampling method. The samples were taken at locations that can be reached along the climbing track at the Mt. Lawu, Mt. Ungaran and Mt. Slamet. Liverworts with Bazzania characters were taken from various substrates (trees, decayed wood, soil, and rocks). Each different specimen collected were packed separately as much as possible. Samples collected were put into paper envelopes. In each envelope is given: collection number, collector name, date, location, and habitat samples. The morphological characters in the field were observed using a hand lens and noted.

Characterization of herbarium specimen was conducted by observing the morphological and anatomical feature of gametophytes using light microscope at $40 \mathrm{x}$ to $1000 \mathrm{x}$ magnification and optilab. The feature observed was the stem, lateral leaf, underleaves (amphigastria) and microphyll. Identification of species was made by comparing the results of characterization with identification key, description and illustration in the following literatures, such as: Evans (1933), Hattori and Mizutani (1958), Meijer (1960), Kitagawa (1967,1977, 1979, 1980), Mizutani (1967), Pócs (1969), Mizutani and Chang (1986), Gradstein (2011), Zhou et al. (2012), Meagher (2015), Cheah and Yong (2016), and Bakalin (2016).

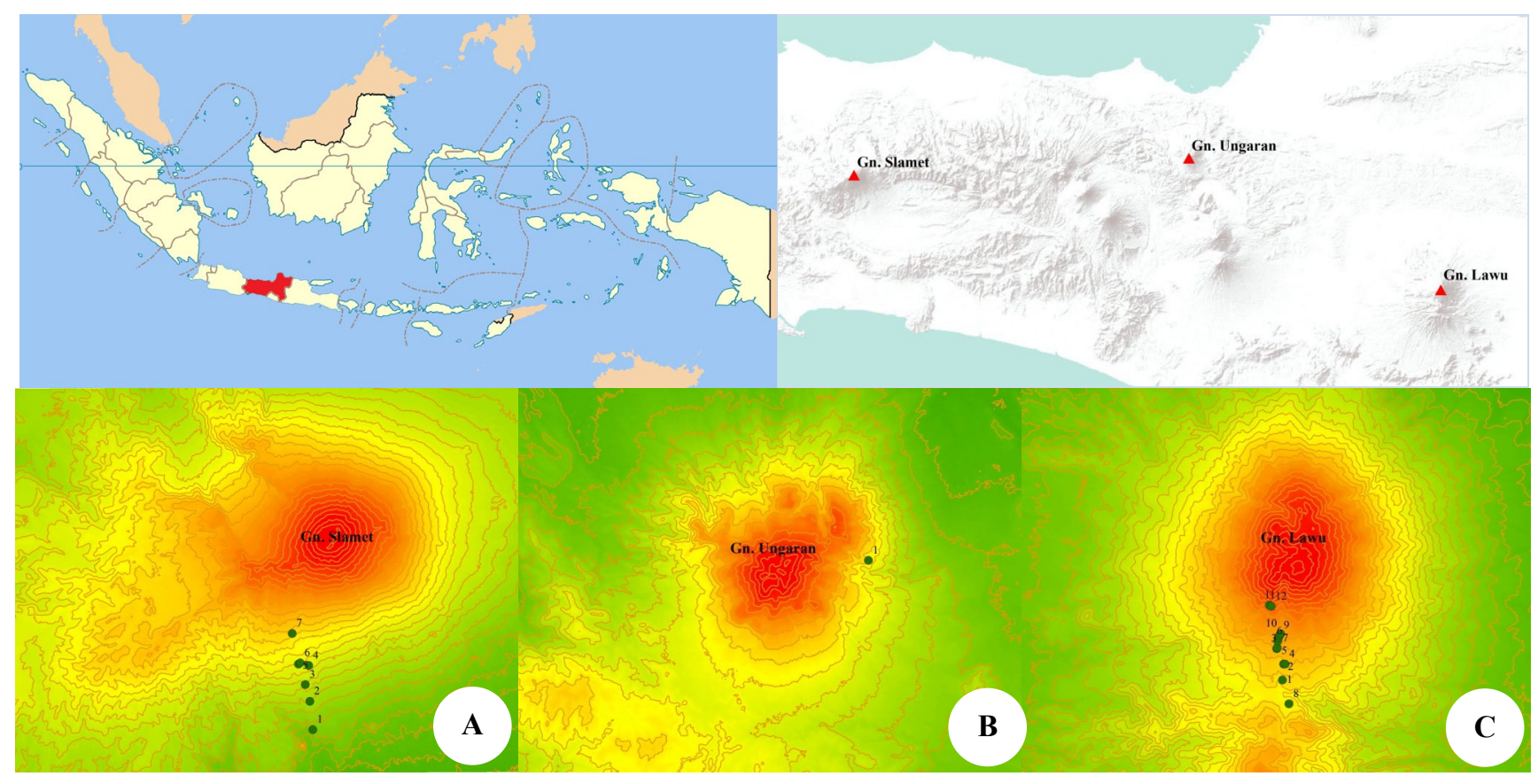

Figure 1. The study area of Bazzania diversity: A. Mt. Lawu, B. Mt. Slamet, C. Mt. Ungaran, Central Java, Indonesia. Note: Bazzania site collection 
The specimen has been identified and named then confirmed to www.theplantlist.org and www.gbif.org. The species description is accompanied by distribution information based on the literature. The specimens were stored in the herbarium of Laboratory of Plant Systematics (LabPS), Faculty of Biology, Universitas Gadjah Mada, Yogyakarta, Indonesia.

\section{RESULTS AND DISCUSSION}

A total of 37 sheets of herbarium specimens have been collected from the fieldwork, 16 samples from Mt. Lawu, five samples from Mt. Ungaran and 16 samples from Mt. Slamet. The results showed no sporophytes or gametangium (archegonium and antheridium). Therefore, morphological and anatomical characterization refers to the vegetative character of the gametophyte.

Bazzania has characteristic features: pseudodichotomous lateral branching, leaves incubous, almost leaf apex with tridentate, large underleaves, and has long branching ventral flagelliformis. Morphological variation of leaves includes dorsal leaf insertion, shape, size, margin, leaf apex (tooth), the presence of appendages or auricles and leaf cells. Underleaves morphological variation is the arrangement, attachment with stem, attachment with leaves, shape, base, apex, size, cells and the presence of auricles. Meanwhile, a variation of microphyll is basal, margin and apex.

Based on the characterization of 37 herbarium specimens can be identified 11 species of Bazzania. Eight species of which are previously known as Java, namely $B$. calcarata, B. japonica, B. javanica, B. pectinata, $B$. praerupta, $B$. serpentina, $B$. spiralis and $B$. tridens. Identification also gets three new recording species for Bazzania in Java, that is B. fauriana, B. perfalcata and B. succulenta. This distribution of species is three species from Mt Lawu, namely $B$. tridens, $B$. praerupta and $B$. japonica; four species from Mt Ungaran, namely $B$. fauriana, B. praerupta, B. serpentina and B. tridens, eight species from Mt. Slamet, namely $B$. calcarata, $B$. fauriana, $B$. javanica, B. pectinata, B. perfalcata, $B$. spiralis, $B$. succulenta and $B$. tridens. Thus the results of this study provide additional records of Bazzania diversity in Java. Meanwhile, for Central Java, the research is the first report on Bazzania diversity.

Based on the results of the characterization, the key to species can be created, to further facilitate the recognition of Bazzania in Central Java.

\section{Key to the species Bazzania in Central Java, Indonesia}

1a. Dorsal leaf insertion on the stem oblique, extending beyond and overlapping on the median line of the stem. Dorsal and ventral base of lateral leaf subcordate to cordate, ventral base of leaf rounded

1b. Dorsal leaf insertion on the stem straight or extending beyond on the median line of the stem but not overlapping. Dorsal and ventral base of leaf subcordate, ventral base of leaf simple 2a. Leaves distichous, leaf margin entire, fragile or not .......... $2 b$. Leaves sub or opposite, leaf margin serrulate, fragile ....

3a. Underleaf inserted transversal or arched, underleaf rectangular

3b. Underleaf inserted arched, underleaf not rectangular

4a. Leaf plane, dorsal and ventral base of leaf with few sharp teeth. Teeth of leaf apex long, acute to acuminate, occasionally hooked and easily broken off. Underleaf inserted arched, base with dentate auricles ...... $\quad$ B. calcarata

$4 \mathrm{~b}$. Leaf incurved, ventral base rounded, the teeth of leaf apex mostly large, acute to acuminate. Underleaf inserted transversal B. fauriana

5a. Leaf with posterior of tooth long, acute, occasionally finger likes. Basal underleaf not auricle, mostly chlorophyllous cells with hyaline cells at the apex and reflexed. Microphyll apex acuminate.................... B. serpentina

$5 b$. Leaf with posterior of the tooth not acute. Basal underleaf with auricle, apex not reflexed, chlorophyllous cells. Microphyll toothed

6a. Dorsal margin of leaf very arched, lateral apex mostly acute with tridentate, the teeth divergent, mostly long, caudate, and easily broken off. Median leaf cells elongate hexagonal with large trigone, nodulose. Underleaf contiguous to imbricate, large orbicular with

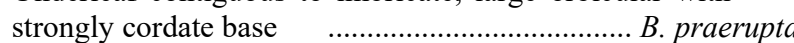

6b. Dorsal margin of the leaf is slightly arched, the teeth acute to acuminate. Median leaf cells rectangular with small trigone, not nodulose. Underleaf distant, reniformis, with auricles at underleaf base ............ B. javanica

7a. Stem size large (across in diameter $>14$ cells). Leaf ovate-triangular, basal ventral of the leaf with small auricles, leaf cell with large trigone, nodulose, confluent, underleaf base cordate

7b. Stem size median (across the diameter 10-14 cells), leaf falcate-linear, basal ventral of lateral leaf no auricles, leaf cell with median trigone, not nodulose, not confluent, underleaf base straight B. perfalcata

8a. Leaf apex rounded with indistinctly tridentate, at the teeth with accessory minute denticulation. Underleaf distant or contiguous, connate with basal leaf ...... B. spiralis

8b. Leaf apex rounded, serrulate, not dentate, the ventral base margins of leaf arched and at the middle, there are constricting. Underleaf contiguous-imbricate, not connate but very close with basal leaf B. succulenta

9a.Underleaf mostly reflexed at the apex, irregularly dentate, the teeth acute, the margin mostly sinuate-angular and often denticulate; underleaf cells chlorophyllous .. B. japonica

9b.Underleaf not reflexed at the apex, truncate or emarginate, margin not denticulate, underleaf cells chlorophyllous or most hyaline cells

10a. Lateral leaf lanceolate, long-wide ratio of leaf $>2,5$. Underleaf cells chlorophyllous. Microphyll margin entire B. pectinata

10b. Lateral leaf ovate-oblongs, long-wide ratio of leaf $<2,5$. The underleaf cells almost composed of hyaline cells, chlorophyllous cells only at the basal underleaf. Microphyll margin emarginate.. B. tridens 


\section{Description and taxonomy}

The detailed description, synonyms, distribution, and figure of Bazzania in the three mountains (Mt. Lawu, Mt. Ungaran and Mt. Slamet) in Central Java are provided below.

\section{Bazzania calcarata (Sande Lac.) Shiffn.}

Bazzania calcarata (Sande Lac.) Shifffn., Consp. Hepat. Archip. Indici 149 (1898). Figure 2.A-H

Synonym: Mastigobryum calcaratum Sande Lac., Ann. Mus. Bot. Lugduno-Batavi 1: 304, 1864 (Sande Lacoste 1864).

Description: Plant green-brownish, robust, 2.96-3.43 $\mathrm{mm}$ wide, branching lateral pseudodichotomous, divergent at $83.2^{\circ}-9.24^{\circ}$. Stem ellipsoid in cross-section, about 14 thick cells, $0.24-0.26 \mathrm{~mm}$ across in diameter, stem circle 34 cells, merophyte ventral 12-13 cells. Leaves distichous, incubous, obliquely inserted but not overlapping on the median line of the stem, distant to weakly imbricate basally, divergent at $82.7^{\circ}-9.6^{\circ}$ with the stem; asymmetrical, falcate, lanceolate-ovate, $1.41-1.83 \mathrm{~mm}$ long, $0.57-0.86 \mathrm{~mm}$ wide, long/wide ratio 2.4-2.9; narrowed toward the apices, the dorsal base subcordates, the ventral base inflated with a few sharp teeth (Figure 2.C); the dorsal margin entire to weakly repand at distal of leaf; the apex mostly acute with deeply tridentate, sometimes bidentate, the teeth mostly long, acute to acuminate, occasionally hooked and easily broken off, the anterior tooth 4-6 cells long, 3-4 cells wide, the median tooth 5-7 cells long, 4-7 cells wide, the posterior tooth 4-5 cells long, 3-5 cells wide, sinus between teeth sharply such as the letter V; leaf-cells $37.00-44.86 \times 23-27.85 \mu \mathrm{m}$ in the base, 35-54.86 x 16.87-18.44 $\mu \mathrm{m}$ in the middle, 34-36.53 x 22-23.88 $\mu \mathrm{m}$ near the apex; trigones very large, $15-17 \mathrm{x}$ 11-16 $\mu \mathrm{m}$, strongly nodulose, confluent (Figure 2.H). Underleaf distant, inserted arched upward (Figure 2.F), plane, rectangular, 0.4-0.5 mm long, 0.26-0.4 mm wide, long/wide ratio 1.09-1.12, larger from the stem, at the base arising irregularly toothed auricle, the whole margin lobulated dentate (Figure 2.G); underleaf cells chlorophyllous. Microphyll at the flagellae oblong, 165.3$166.0 \mu \mathrm{m}$ long, 132.48-135.71 $\mu \mathrm{m}$ wide, basal transverse, margin entire, apex dentate (Figure 2.E).

Specimen examined: Indonesia: Java: Central Java: Mt. Slamet, 1500-1697 m asl., terrestrial, September 2015. L. Khotimperwati S8 and S15.

Distribution: New Guinea, Borneo, Java, Sumatra, Malaya, Philippines, Malacca (Stephani 1909; Meijer 1960; Soderstrom et al. 2010; Petiot 2011), New Guinea, Philippines (Kitagawa 1979).

Note: This species is distinguished from others species by the ventral base of leaf inflated with sharp teeth, the whole margin of underleaf lobulated dentate, and at the base arising irregularly toothed auricle. $B$. calcarata have underleaf resembles B. fauriana and B. japonica (Figure 3.D and 4.C).

\section{Bazzania fauriana (Steph.) S.Hatt.}

Bazzania fauriana (Steph.) S.Hatt., Bot. Mag. (Tokyo) 59 (693/694): 27, 1946 (Hattori 1946). Figure 3.A-E.
Synonym: Mastigobryum faurianum Steph., Bull. Herb. Boissier (sér. 2) 8 (11): 843 (467), 1908 (Stephani 1908a); $B$. nodulosa Horik., J. Sc. Hiroshima Univ.ser.b, div. 2,2:199 (1934); Hatt., Bull. Tokyo Sc. Mus. 11: 18 (1944); B. kiushiana Hatt., Bull. Tokyo Sc. Mus. 22: 19 (1944); B. aequitexta Herz., J. Hatt. Bot. Lab. 14: 41 (1955).

Description: Plant yellowish-green, subrobust to robust, 2.7-3.15 mm wide, branching lateral pseudodichotomous, inclined to divergent at $58.09^{\circ}-94.75^{\circ}$. Stem ellipsoid in cross-section, about 10 thick cells, $0.23-0.26 \mathrm{~mm}$ across in diameter, stem circle 25 cells, merophyte ventral 7-8 cells. Leaves fragile, distichous, incubous, the dorsal insertion oblique and overlapping on the stem, imbricate, inclined to divergent at $63.9^{\circ}-99.8^{\circ}$ with the stem, deflexed, asymmetrical, falcate, lanceolate-ovate to sublinear (Figure 3.B), $1.46-2.12 \mathrm{~mm}$ long, $0.55-0.91 \mathrm{~mm}$ wide, long/wide ratio 2.5-2.7; the base of leaf strongly arched, narrowed toward the apices; the dorsal base cordates; the ventral base rounded; the margin dorsal leaf entire to weakly repand at distal leaf; the apex mostly acute with tridentate, sometimes bidentate, the teeth mostly large, acute to acuminate, the anterior tooth 2-3 cells long, 2-3 cells wide, the median tooth 4-7 cells long, 3-6 cells wide, the posterior tooth $4-5$ cells long, $4-5$ cells wide, the sinus between teeth lunulate; leaf cells rectangular to hexagonal to isodiametric, $39.32-42.63 \times 21.69-25.08 \mu \mathrm{m}$ in the base, $31.90-39.06 \times 9.65-22.12 \mu \mathrm{m}$ in the middle, 29.19-32.59 x 23.01-23.16 $\mu \mathrm{m}$ near the apex; trigones large, $8.56-11.35 \mathrm{x}$ 7.28-9.7 $\mu \mathrm{m}$, strongly nodulose, confluent. Underleaf contiguous to overlap (Figure 3.A), transversely inserted; incurved, usually connate at the base with one side of the lateral leaf, fragile lengthwise, widely oblong to rectangular, $0.54-1.03 \mathrm{~mm}$ long, $0.45-0.77 \mathrm{~mm}$ wide, long/wide ratio 1.17-1.39; larger from the stem, sometimes twice as wide as the stem, adaxially convex, sharp dentate at the apex, the whole margin lobulate-sharp dentate (Figure 3.D); underleaf cells chlorophyllous. Microphyll at flagellae ovate, 166-242 $\mu \mathrm{m}$ long, 136.34-177.18 $\mu \mathrm{m}$ wide, basal transverse, margin entire, apex dentate (Figure 3.E).

Specimen examined: Indonesia: Java: Central Java: Mt. Ungaran (2040 m asl.) on the base of a tree, Mt. Slamet (1500 m asl.), terrestrial; May-September 2015. L. Khotimperwati, S7 and U3.

Distribution: Hongkong (So and Zhu 1996), China, Japan, Taiwan, Vietnam (Mizutani and Chang 1986; Pócs 1969; Luong and Ho 2013), Sumatra (Lestari and Ariyanti 2017), Java (Central Java, a new record).

Note: This species is a new record in Java, collected from Mount Slamet at $1500 \mathrm{~m}$ asl. on terrestrial. $B$. fauriana was also reported in Gunung Leuser National Park-Sumatra as a new record from Malesiana regions (Lestari and Ariyanti 2017). B. fauriana resembles B. japonica, but underleaf of $B$. fauriana not reflexed at apex, underleaf is more rectangular than $B$. japonica. B. fauriana is differentiated to the other species by sublinear leaf, amphigastria large, the whole margin and apex lobulatesharp dentate, leaf cells and underleaf cells with large and nodulose trigones. Distribution of B. fauriana is limited to montane forests. 
Bazzania japonica (Sande Lac.). Lindb.

Bazzania japonica (Sande Lac.) Lindb., Acta Soc. Sci. Fenn. 10: 224, 1872 [1873] (Lindberg 1872b). Figure 4.A-E.

Synonym: Mastigobryum japonicum Sande Lac., Ann. Mus. Bot. Lugduno-Batavi 1: 303, 1864 (Sande Lacoste 1864). B. zhekiangensis Chang, Bull. Bot. Res. 4 (3): 86-87 (1984)

Description: Plants green to olive green, phylliform to robust, 2.1-3.5 $\mathrm{mm}$ wide, branching lateral pseudodichotomous, divergent at $80^{\circ}-100^{\circ}$. Stems suborbicular to elliptical in cross-section, about 12 thick cells, 0.19-0.24 mm across in diameters, stem circle 26 cells, merophyte ventral 9-12 cell. Leaves subopposite to opposite, incubous, imbricate, divergent at $75.50^{\circ}-93.50^{\circ}$ with the stem; the dorsal leaf insertion is oblique but not extending beyond the median line of the stem, plane; asymmetrical, falcate, ovate to oblong, 1.2-1.65 mm long, $0.54-0.87 \mathrm{~mm}$ wide, long/wide ratio 1.7-2.2; the dorsal base subcordate, the margin dorsal leaf entire to weakly repand; wide at basal, narrowed and truncate-tridentate at apex, sometimes 2-4 teeth, the teeth triangular, acute to acuminate, sometimes with additional teeth, the anterior tooth 4-7 cells long, 4-7 cells wide, the median tooth 4-6 cells long, 3-7 cells wide, the posterior tooth 3-6 cells long, 3-6 cells wide, sinus lunulate but sometimes deeply such as the letter V; leaf cells quadrate to rectangular, 36.66-49.33 x $21.35-33.63 \mu \mathrm{m}$ in the base, $34.17-44.46 \times 17.68-24.62$ $\mu \mathrm{m}$ in the middle, $21.69-30.32 \times 15.99-20.68 \mu \mathrm{m}$ near the apex, trigones small to medium, 4.5-9.27 x 3.5-6.1 $\mu \mathrm{m}$, nodulose. Underleaf distant to imbricate, transversely inserted, usually connate at the base with one side of the lateral leaf, broadly orbicular-rectangular, $0.33-0.73 \mathrm{~mm}$ long, 0.4-0.84 mm wide, long/wide ratio 0.72-1.02; mostly reflexed at the apex (Figure 4.A), irregularly dentate, corniculate or denticulate, the teeth acute, sometimes with pappilous at the apex, the margin mostly sinuate-angular and often denticulate (Figure 4.D); underleaf cells chlorophyllous. Microphyll at flagellae triangular, 111.3125.26 $\mu \mathrm{m}$ long, 123.8-142.23 $\mu \mathrm{m}$ wide, basal transverse, margin entire, apex emarginate (Figure 4.E).

Specimen examined: Indonesia: Java: Central Java: Mt. Lawu (1986-2531 m asl.) on terrestrial and base of tree. May 2015. L. Khotimperwati L2, L3, L4, L5, L6, L7, L8.

Distribution: Sumatra, Thailand, India, China, Vietnam, Japan, Soviet (So 1996; Kitagawa 1967; Pocs 1969; Mizutani and Chang 1986; Zhou et al. 2012; Bakalin 2016; Shukkharak et al. 2014; Sari 2015), Java (Soderstrom et al. 2010), Sri Lanka (Long and Rubasinghe 2014).

Note: B. japonica is differentiated from the others species by underleaf margin denticulate, reflexed at the apex. According to Hattori and Mizutani (1958), B. japonica in the section connatae which is closely related to $B$. yoshinagana. However, B. yoshinagana has bigger thallus than B. japonica and not narrowed at tips of leaves.
Synonym: Mastigobryum javanicum Sande Lac., Ned. Kruidk. Arch. 3: 418, 1854 [1855] (Sande Lacoste 1854).

Description: Plants green, phylliform, 1.3-2.08 mm wide. Branching lateral pseudodichotomous, divergent at $60.78^{\circ}-92.97^{\circ}$. Stem orbicular in cross-section, about 10 thick cells, $0.24-0.26 \mathrm{~mm}$ across in diameter, stem circle 34 cells, merophyte ventral 7-9 cells. Leaves distichous, incubous, obliquely inserted and overlapping on the median line of the stem, imbricate, inclined to divergent at $56.62^{\circ}$ $83.57^{\circ}$ with the stem; asymmetrical, weakly falcate, ovatetriangular, mostly $1.0-1.2 \mathrm{~mm}$ long and $0.45-0.60 \mathrm{~mm}$ wide, long/wide ratio 2.0-2.1, the dorsal half-leaf ovate, tapering to an acute the apex; the margin entire; the apex strongly 3 teeth, acute to acuminate but dominant acuminate, the anterior tooth 5-7 cells long, 4-5 cells wide, the median tooth 5-9 cells long, cells 4-8 wide, the posterior tooth 4-6 cells long, 2-5 cells wide, sinus between the teeth deeply such as the letter V; leaf-cells hexagonal to rectangular, 28.90-32.46 x 18.42-22.31 $\mu \mathrm{m}$ in the base, 23.73-29.09 x 18.95-28.65 $\mu \mathrm{m}$ in the middle, 26.09-27.70 x 18.72-20.59 $\mu \mathrm{m}$ near the apex, cells with small to middle trigones, 4.9-5.11 x 3.7-4.34 $\mathrm{m}$, small nodulose (Figure 5.C). Underleaf distant, narrowly connate at the base with one side of the lateral leaf; reniform to circular, mostly wider than long (Figure 5.D), typically $0.24-0.32 \mathrm{~mm}$ long, $0.35-0.47 \mathrm{~mm}$ wide, long/wide ratio $0.65-0.86$; inserted to the stem hollows, the basal concave with auricle, the margin entire; the apex obtuse with small papilla; underleaf cells chlorophyllous. Microphyll at flagellae triangular, 138.9-148.72 $\mu \mathrm{m}$ long, 156.9-198.19 $\mu \mathrm{m}$ wide, basal transverse, margin entire, apex retuse (Figure 5.D)

Specimen examined: Indonesia: Java: Central Java: Mt. Slamet (1697-1941 m asl.) on terrestrial. September 2015. L. Khotimperwati S12, S13, S14.

Distribution: Java, Sumatra, Moluccas (Meijer 1960; Soderstrom et al. 2010), Thailand, Hawaii (Kitagawa 1967), Australia (Queensland) (Meagher 2015).

Note: B. javanica resembles B. praerupta, but it has more distant underleaf (Meijer 1960), the less closely imbricate of leaves, size of leaf and trigones are smaller than B. praerupta (Kitagawa 1967). The leaves of $B$. praerupta are distinctly dilated on the basal margin (Meagher 2015). In the study, teeth of B. praerupta is longer than B. javanica (Figure 5.A, 8.C).

\section{Bazzania pectinata (Lindenb. et Gottsche) Schiffn.}

Bazzania pectinata (Lindenb. et Gottsche) Schiffn., Nova Acta Acad. Caes. Leop.-Carol. German. Nat. Cur. 60 (2): 259, 1893 (Schiffner 1893a). Figure 6.A-E

Synonym: Mastigobryum pectinatum Lindenb. et Gottsche, Sp. Hepat. (Lindenberg) 8-11: 84, 1851 (Lindenberg and Gottsche 1851b). Jungermannia tridens var. $\beta$ Ness, Hep. Jav. 1830, 61-227. M. tridens var. $\beta$ Gottsche, Linden b. et Ness, Syn. Hep. 1845, 227.

\section{Bazzania javanica (Sande Lac.) Schiffn.}

Bazzania javanica (Sande Lac.) Schiffn., Consp. Hepat. Arch. Ind.: 163, 1898 (Schiffner 1898b). Figure 5.A-E 

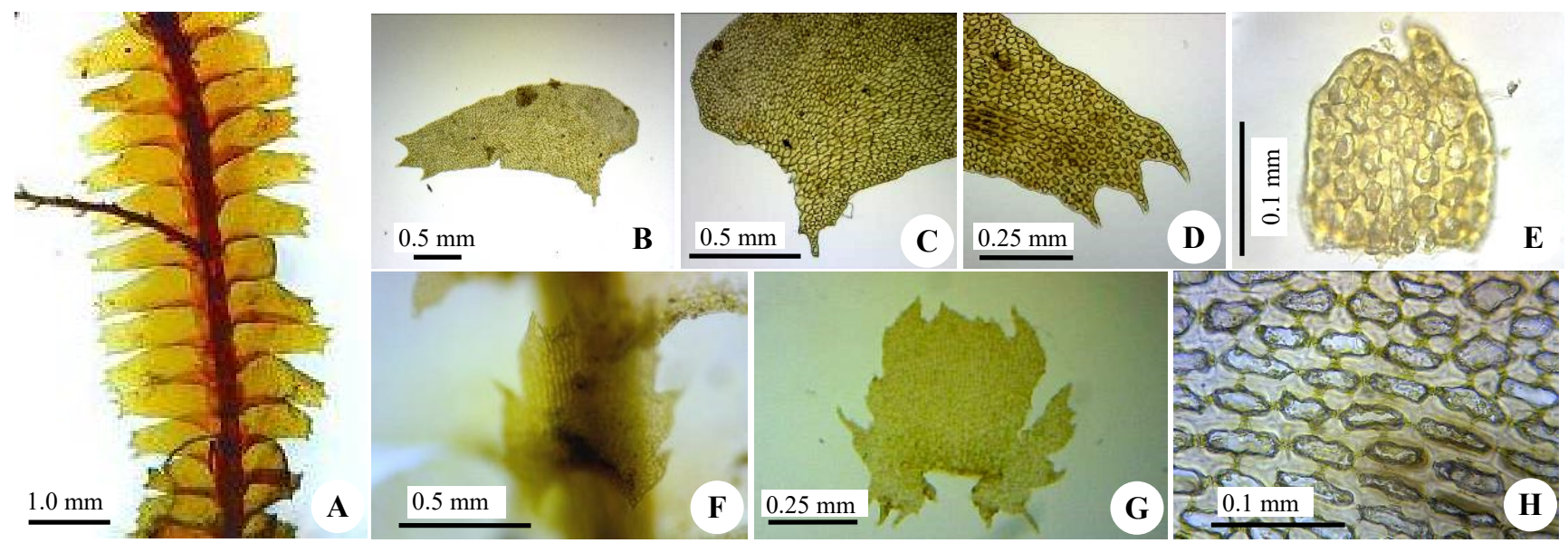

Figure 2. Bazzania calcarata: A. Thallus, B. Leaf, C. Basal ventral of leaf, D. Leaf apex, E. Microphyll, F. Underleaf inserted, G. Underleaf, H. Leaf cell
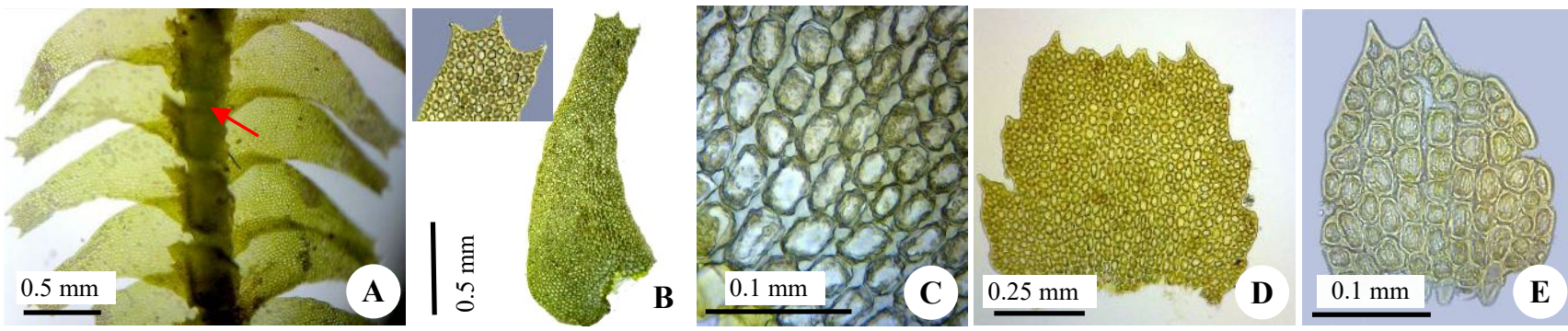

Figure 3. Bazzania fauriana: A. Thallus, B. Leaf, C. Leaf cells, D. Underleaf, E. Microphyll. Arrow = inserted underleaf on the stem
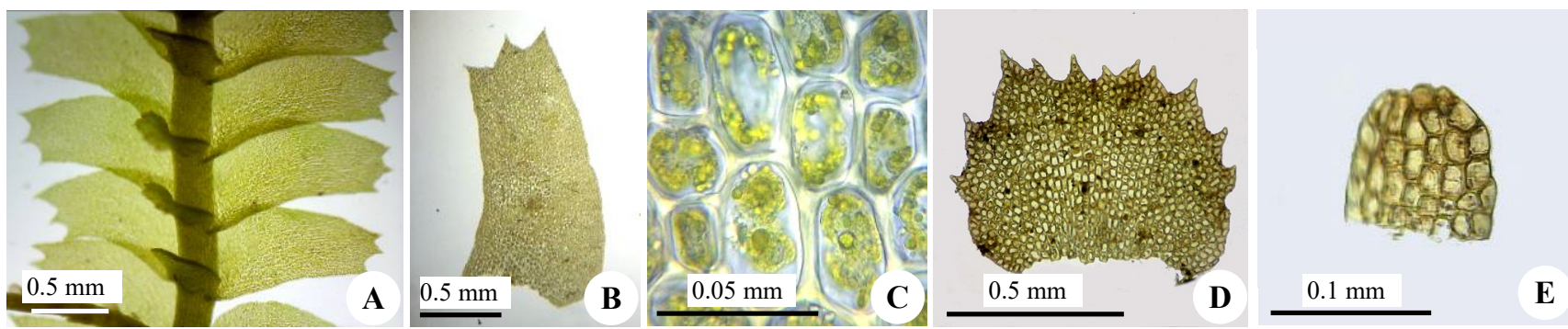

Figure 4. Bazzania japonica: A. Thallus, B. Leaf, C. Leaf cells, D. Underleaf, E. Microphyll
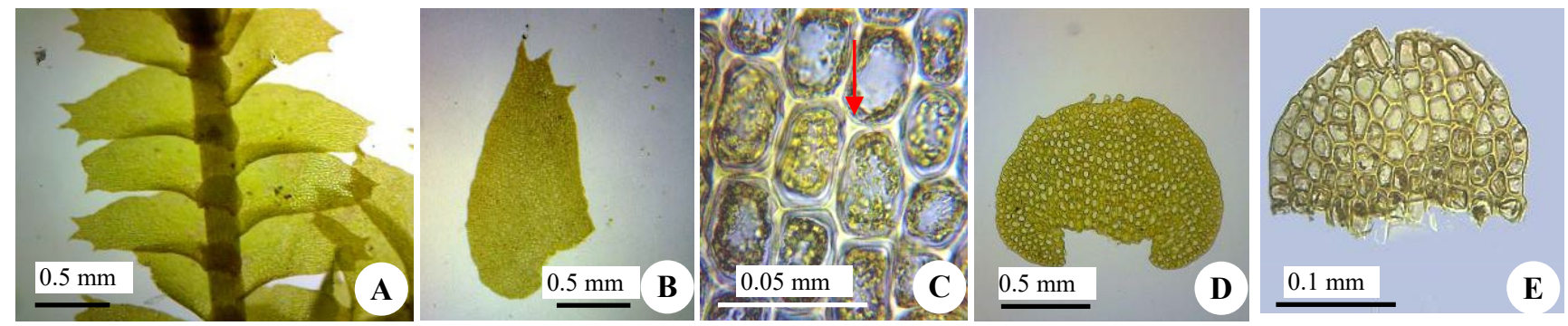

Figure 5. Bazzania javanica; A. Thallus, B. Leaf, C. Leaf cells, D. Underleaf, E. Microphyll, Arrow= trigone 
Description: Plant green-brownish, phylliform to subrobust, 1.26-2.81 $\mathrm{mm}$ wide, branching lateral pseudodichotomous, divergent at $86.4^{\circ}-98.32^{\circ}$. Stem ellipsoid in cross-section, about 12 thick cells, 0.31-0.37 $\mathrm{mm}$ across in diameter, stem circle 26 cells, merophyte ventrals 8-10 cells. Leaves distichous, incubous, dorsal insertion is straight on the stem, distant-contiguous, divergent at $70.6^{\circ}-88.66^{\circ}$ with the stem, asymmetrical, subfalcate, lanceolate, $1.41-1.46 \mathrm{~mm}$ long, 0.56-0.57 $\mathrm{mm}$ wide, long/wide ratio 2.5-2.6 (Figure 6.B); narrowed toward the apices, the dorsal base subcordate, the ventral base simple, the margin of dorsal and ventral entire, the apex truncate tridentate, sometimes bidentate, the anterior tooth 5-6 cells long, 5-6 cells wide, the median tooth 4-7 cells long, 3-5 cells wide, the posterior tooth 3-5 cells long, 4-7 cells wide, sinus between teeth deeply such as the letter $\mathrm{V}$; leaf cells hexagonal-quadrate, $30.89-40.73 \times 19.80$ $24.24 \mu \mathrm{m}$ in the base, $30.85-33.84 \times 20.76-22.04 \mu \mathrm{m}$ in the middle, 24.65-26.07 $x$ 5.94-10.79 $\mu \mathrm{m}$ near the apex, trigone midle to large, 5.94-10.79 $\mathrm{x}$ 4.88-7.24 $\mu \mathrm{m}$, nodulose and sometimes confluent. Underleaf distant, transverse inserted, widely ovate, 0.21-0.26 mm long, 0.26$0.37 \mathrm{~mm}$ wide, long/wide ratio $0.7-0.81$, as wide as to the stem, sometimes smaller than the stem, appressed to the stem, basal straight, the margin entire-repand, the apex truncate-emarginated, sometimes irregularly retuse; the presence of slime papillae; underleaf cells chlorophyllous (Figure 6.D). Microphyll at flagellae ovate, 129.01-158.44 $\mu \mathrm{m}$ long, 112.76-143.266 $\mu \mathrm{m}$ wide, basal transverse, margin entire, apex acute and toothed (Figure 6.E).

Specimen examined: Indonesia: Java: Central Java: Mt. Slamet (1589 m asl.) on terrestrial and base of the tree. May 2015. L. Khotimperwati, S9 and S10.

Distribution: Ambon, Banca, Borneo, Luzon, French Guiana, Sumatra, Java (Evans 1933; Meijer 1960, Souderstrom et al. 2010), Peninsular Malaysia (Cheah and Yong 2016)

Note: This species resembles $B$. densa and $B$. tridens (Meijer 1960), but $B$. densa has recurved underleaf. $B$. pectinata is characterized by higher leaf length/width ratio (2.5-2.6), underleaf as wide as to the stem, sometimes smaller than the stem, truncate at the apex, often irregular retuse, not connate with both side of the lateral leaf, cell underleaf chlorophyllous; big trigones are found in leaf and underleaf. Meanwhile, B. tridens has shorter leaf length/ width ratio (1.8-2.3); cells underleaf hyaline, chlorophyllous cells only at the basal underleaf; smaller trigones are found in leaf and underleaf

\section{Bazzania perfalcata N. Kitag.}

Bazzania perfalcata N. Kitag., J. Hattori Bot. Lab. 47: 135, 1980 (Kitagawa 1980). Figure 7A-H.

Description: Plant green-brownish, robust, 2.97-4.11 $\mathrm{mm}$ wide, branching lateral pseudodichotomous, divergent at $74.89^{\circ}-90.31^{\circ}$. Stem orbicular in cross-section, about 12 thick cells, $0.20-0.31 \mathrm{~mm}$ across in diameter, stem circle 28 cells, merophyte ventrals 8-9 cells. Leaves fragille, opposite (Figure 7.B), incubous, obliquely inserted and overlapping on the median line of stem; very imbricate, divergent at $72.5^{\circ}-78.3^{\circ}$ with stem, subrecurved, asymmetrical, falcate linear, 1.91-2.44 mm long, 0.57-0.75 $\mathrm{mm}$ wide, long/wide ratio 3.10-3.99; the dorsal base cordate, inflated and arching across on the stem, the ventral base rather rounded, the dorsal and ventral margin entire with projecting cell-walls (Figure 7.F), the distal margin serrulate, the apex truncate tridentate (Figure 7.D), often with smaller teeth addition, the teeth acute, the anterior tooth 4-5 cells long, 4-9 cells wide, the median tooth 4-5 cells long, 9-10 cells wide, the posterior tooth 3-8 cells long, 4-11 cells wide, sinus between teeth deeply such as the letter $\mathrm{V}$; leaf cells rectangular to quadrate, 35.59-43.89 $\mathrm{x} 24.05-27.37 \mu \mathrm{m}$ in the base, 27.52-35.68 x 19.25-22.18 $\mu \mathrm{m}$ in the middle, $22.91-28.37 \times 17.36-25.41 \mu \mathrm{m}$ near the apex, trigones medium, 8.63-12.18 $\mu \mathrm{m} \times 6.29-9.12 \mu \mathrm{m}$, strongly nodulose and confluent. Underleaf distant, transverse inserted; recurved, usually connate at the base with one side of the lateral leaf, wide-ovate; $0.25-0.33 \mathrm{~mm}$ long, 0.42-0.51 mm wide, long/wide ratio 0.59-0.66, larger from the stem, basal straight, margin subentire-repand, apex obtuse-emarginate, reflexed, underleaf cells are mostly composed of chlorophyllous, cells of apicals are composed by hyaline cells (Figure 7.G). Microphyll at flagellae ovate, 147.12-151.85 $\mu \mathrm{m}$ long, 197.21-212.36 $\mu \mathrm{m}$ wide; basal transverse, margin serrulate, apex acute and toothed (Figure 7.H)

Specimen examined: Indonesia: Java: Central Java: Mt. Slamet (1589 $\mathrm{m}$ asl.) on terrestrial and base of the tree. May 2015. L. Khotimperwati, S16.

Distribution: New Guinea (Kitagawa 1980), Java (Central Java: New record)

Note: $B$. perfalcata is a new record in Java. This species can be found at Mt. Kaindi (New Guinea), 2200-2350 m asl. in the wet mossy forest, which is characterized by the leaves that are strongly fragile, very long and strongly falcate, so those characters are used as the specific epithet. $B$. perfalcata resembles $B$. zollingeri from Java and Sumatra based on the strongly falcate leaves and small underleaves with reflexed at the apex (Kitagawa 1980). According to Gradstein (2011), B. zollingeri has very small underleaf, narrowed than the stem, without hyaline border and not reflexed. Meijer (1960) explained that characterized $B$. zollingeri was leaves with indistinct twotridentate, trigone small, underleaf hyaline, wider than long or as wide as long and the same width the stem, reflexed at the apex. Meanwhile, the specimen in this study has strongly falcate leaves, fragile but not strongly; small underleaf but wider than the stem, chlorophyllous with the hyaline border in the apex, reflexed at the apex, which is similar to B. perfalcata from New Guinea.

\section{Bazzania praerupta (Reinw., Blume et Nees) Trev.}

Bazzania praerupta (Reinw., Blume et Nees) Trevis., Mem. Reale Ist. Lombardo Sci. (Ser. 3), C. Sci. Mat. 4 (13): 414, 1877 (Trevisan 1877). Figure 8.A-G

Synonym: Jungermannia praerupta Reinw., Blume et Nees, Nova Acta Phys.-Med. Acad. Caes. Leop.-Carol. Nat. Cur. 12 (1): 229, 1824 [1825] (Reinwardt et al. Yn. Hepat. 224 (1845).1824a). Mastigobryum praeruptum (Reinw., Bl. Et Nees) Linden b. in Gott., Linden b \& Nees, Syn. Hepat. 224 (1845). M. decurvum Nees in Gott., 
Linden b. \& Nees, 1.c. 223 (1845). Bazzania decurva (Ness) Trev., 1.c. 414 (1877). M. sandei Steph., Hedwigia 25: 206, pl. 3, fig. 39-43 (1886). B. yakushimensis Horik., J. Sc. Hiroshima Univ. Ser. B. div. 2, 2: 194 (1934). B. pseudotriangularis Horik., J. Sc. Hiroshima Univ. Ser.b, div 2, 2: 194 (1934).

Description: Plant green-brownish, phylliform to robust, 2.1-3.14 $\mathrm{mm}$ wide, branching lateral pseudodichotomous, divergent at $67.15^{\circ}-80.71^{\circ}$. Stem orbicular in cross-section, about 12 thick cells, 0.17-0.27 $\mathrm{mm}$ across in diameter, stem circle 32 cells, merophyte ventral 8-9 cell. Leaves distichous, incubous, obliquely inserted, overlapping on the median line of the stem, distant to tightly imbricate, inclined to divergent at angels $59.6^{\circ}-80.2^{\circ}$ with the stem, strongly deflexed; asymmetrical, falcate, widely ovate-triangular; $1.29-1.84 \mathrm{~mm}$ long, $0.7-$ $1.1 \mathrm{~mm}$ wide, long/wide ratio, 1.7-1.8; narrowed toward the apices, the dorsal base cordate, the ventral base arched; the margin entire; the dorsal base margin very arched, the apex mostly acute with tridentate, the teeth divergent, mostly long (Figure 8.C), caudate, and easily broken off, the anterior tooth 7-13 cells long, 3-7 cells wide, the median tooth 7-13 cells long, 3-7 cells wide, the posterior tooth 4-11 cells long, 3-6 cells wide; sinus between teeth sharp as letter V; leaf cells rectangular-hexagonal-quadrate, $29.46-40.91 \times 16.35-25.32 \mu \mathrm{m}$ in the base, $24.88-35.30 \mathrm{x}$ $16.85-20.8 \mu \mathrm{m}$ in the middle, $23.05-29.38 \times 17.22-20.50$ $\mu \mathrm{m}$ near the apex, trigones large, 7.13-12.5 x 6.28-9.3 $\mu \mathrm{m}$, nodulose, confluent (Figure 8.C). Underleaf distantcontiguous to imbricate, inserted arched (Figure 8.E), orbicular-oblate, larger than the stem, 0.35-0.79 mm long, $0.44-0.89 \mathrm{~mm}$ wide, long/wide ratio $0.87-1.00 ; 1.5$ times as wide as the stem, the basal cordate with auricle, the margin entire to repand, with thickened of nodulose; the apex retuse-obtuse, with papilla; underleaf cells chlorophyllous (Figure 8.F). Microphyll at flagellae ovate-triangular, 226.9-249.65 $\mu \mathrm{m}$ long, 174.35-179.95 $\mu \mathrm{m}$ wide; basal transverse, margin entire, apex retuse and toothed (Figure 8.G).

Specimen examined: Indonesia: Java: Central Java: Mt. Ungaran (2040 m asl.) Mt. Lawu (2052-2531 m asl.) on terrestrial and base of the tree. May 2015. L. Khotimperwati U4, L9, L13, L16.

Distribution: Java, Sumatra, Borneo, Moluccas (Meijer 1960; Soderstrom et al. 2010), Southeastern Asia, extending to the Himalaya (Kitagawa 1967; Mizutani 1967), New Guinea (Kitagawa 1980), China (Mizutani and Chang 1986; Zhou et al. 2012).

Note: This species is easy recognized by long divergent teeth, orbicularly underleaf with the strongly cordate base, leaf, and underleaf-cells with large trigones, nodulose, confluent (Kitagawa 1967; Mizutani 1967). B. praerupta resembles $B$. javanica, and both are distinguished by the shape of underleaf, basal margin of leaves, teeth, and trigones (described in B. javanica).

\section{Bazzania serpentina (Nees) Trevis.}

Bazzania serpentina (Nees) Trevis., Mem. Reale Ist. Lombardo Sci. (Ser. 3), C. Sci. Mat. 4 (13): 415, 1877 (Trevisan 1877). Figure 9.A-E.

Synonym: Jungermannia serpentina Nees, Enum. Pl. Crypt. Javae: 62, 1830 (Nees, 1830).

Description: Plant green, phylliform, 2.1-2.35 mm wide; branching lateral pseudodichotomous, inclined to divergent at $68.5^{\circ}-81.93^{\circ}$. Stem ellipsoid in cross-section, about 10 thick cells, $0.22-0.26 \mathrm{~mm}$ across the diameter, stem circle 29 cells, merophyte ventrals 13-16 cells. Leaves distichously arranged on the stem, incubous, obliquely inserted, overlapping on the median line of the stem, imbricate, verry deflexed, divergent at $75.5^{\circ}-80.2^{\circ}$ with the stem, asymmetrical, falcate, ovate-triangular (Figure 9.B); 1.37-1.58 mm long, 0.64-0.77 mm wide, long/wide ratio 1.78-2.21; widest at its base, narrowed toward the apices, the dorsal base cordate, the ventral base incurved, the dorsal margin entire; the apex oblique tridentate, mostly long teeth, the anterior tooth 5-6 cells long, 3-4 cells wide, the median tooth 3-4 cells long, 3-4 cells wide, the posterior tooth 3-4 cells long, 2 cells wide, acute, occasionally finger likes, and easily broken off, sinus between teeth lunulate; leaf-cells hexagonal-rectangularisodiamtric, 30.33-50.02 $\times 22.38-44.72 \mu \mathrm{m}$ in the base, 29.2-34.8 x 18.38-24.57 $\mu \mathrm{m}$ in the middle, 23.67-32.34 $\mathrm{x}$ 18.53-21.92 $\mu \mathrm{m}$ near the apex; trigones medium, 8.18$13.32 \times 5.92-8.04 \mu \mathrm{m}$, strongly nodulose, confluent (Figure 9.C). Underleaf distant, inserted arched upward; adaxially convex, reflexed at apex (Figure 9.D), usually connate at base with one side of lateral leaf, orbicular; 0.4-0.5 mm long, 0.37-0.49 $\mathrm{mm}$ wide, long/wide ratio 0,93-1,02, larger from the stem, the basal cordate, the margin entire, underleaf cells mostly chlorophyllous, apical cells with 1-2 rows hyaline cells. Microphyll at flagellae ovate, 162.05$184.50 \mu \mathrm{m}$ long, 153.26-182.83 $\mu \mathrm{m}$ wide, base transversal, margin entire, apex acute (Figure 9.E).

Specimen examined: Indonesia: Java: Central Java: Mt. Ungaran (2040 m asl.) at the base of a tree. May 2015. L. Khotimperwati. U1.

Distribution: Sumatra, Borneo, Java, New Guinea, Solomon Island (Meijer 1960; Kitagawa 1977; Kitagawa 1980, Soderstrom et al. 2010), Peninsular Malaysia (Cheah and Yong 2016).

Note: B. serpentina is easy recognized by strongly deflexed and falcate leaves, trigon medium, nodulase, orbicular underleaf with reflexed apices where the cells are composed of hyaline.

\section{Bazzania spiralis (Reinw., Blume et Nees) Meijer.}

Bazzania spiralis (Reinw., Blume et Nees) Meijer, Blumea 10 (2): 381, 1960 (Meijer 1960). Figure 10.A-I

Synonym: Jungermannia spiralis Reinw., Blume et Nees, Nova Acta Phys.-Med. Acad. Caes. Leop.-Carol. Nat. Cur. 12 (1): 231, 1824 [1825] (Reinwardt et al. 1824a). 

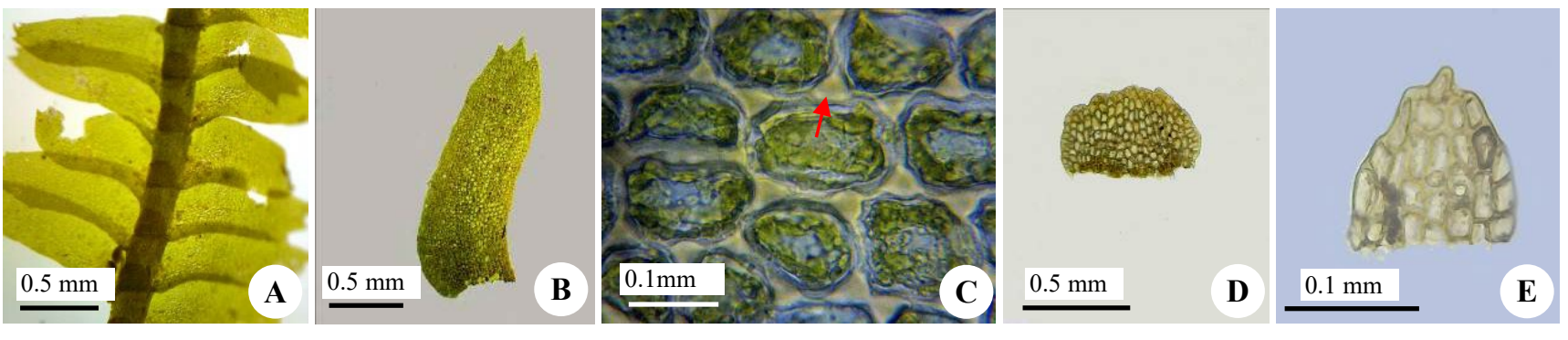

Figure 6. Bazzania pectinata; A. Thallus, B. Leaf, C. Leaf cells, D. Underleaf, E. Microphyll, Arrow= trigone
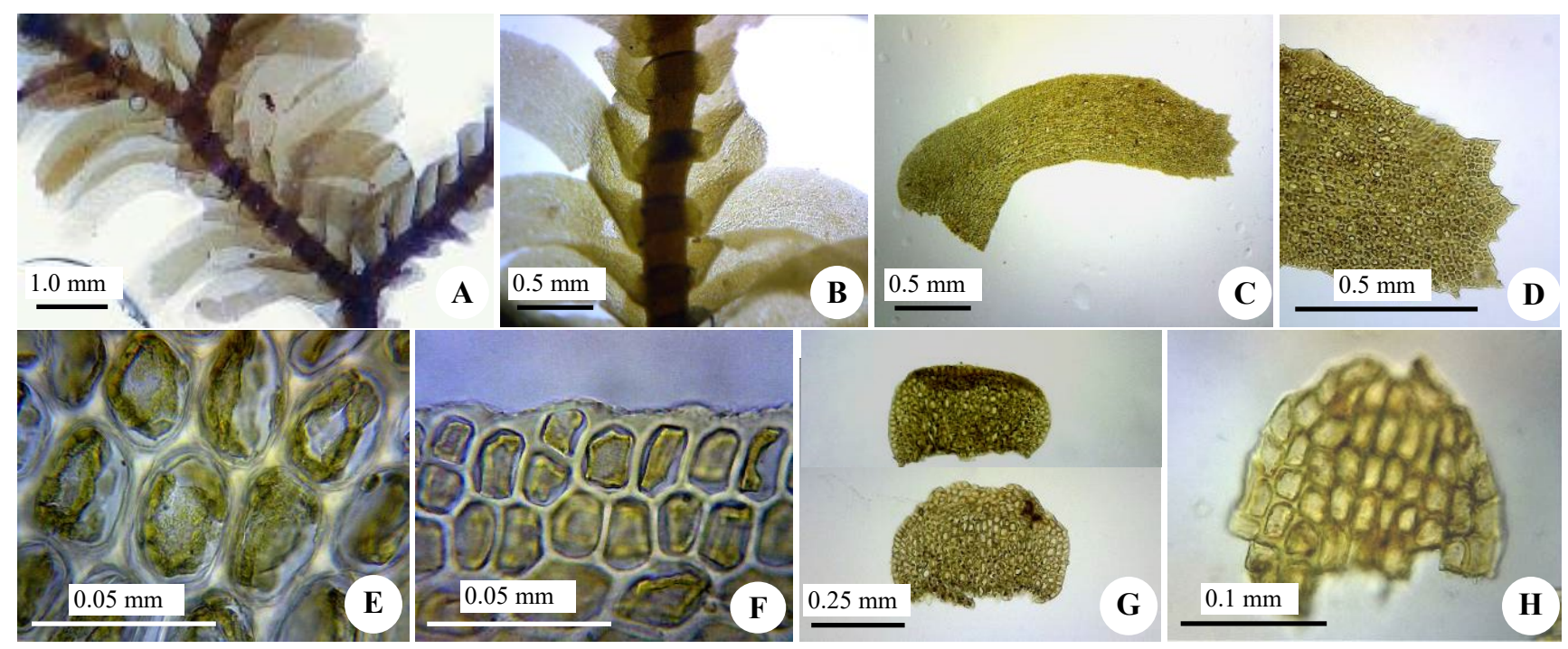

Figure 7. Bazzania perfalcata, A. Thallus, B. Part of thalus, C. Leaf, D. Leaf apex, E. Leaf cells, F. Leaf dorsal margin, G. Underleaf, H. Microphyll

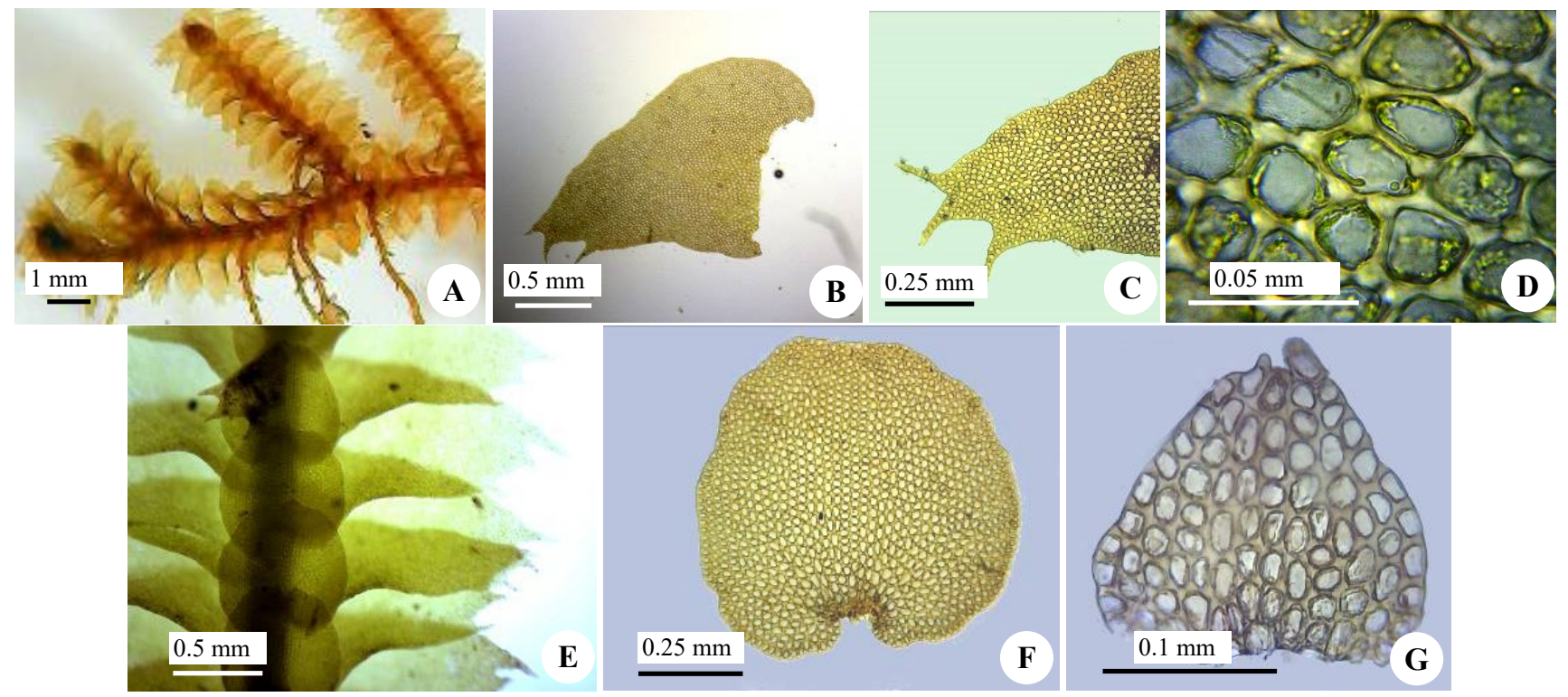

Figure 8. Bazzania praerupta: A. Thallus, B. Leaf, C. Leaf apex, D. Leaf cells, E. Part of thallus, F. Underleaf, E. Microphyll 
Description: Plant yellowish green to green brownish, robust, 2.24-3.92 $\mathrm{mm}$ wide; branching lateral pseudodichotomous, inclined to divergent at $66.07^{\circ}$ $105.59^{\circ}$. Stem orbicular in cross-section, about 14 thick cells, 0.24-0.46 mm across in diameter, stem circle 36 cells, merophyte ventrals 8-12 cells. Leaves opposite, incubous, obliquely inserted, overlapping on the median line of stem, very imbricate, inclined to divergent at $63.3^{\circ}-89.3^{\circ}$ with the stem, deflexed, very curved ventrally, strongly asymmetrical, not falcate, triangular-ovate to ligulateovate (Figure $8 \mathrm{C}$ ); 1.833-2.55 mm long, 1.19-1.34 mm wide, long/wide ratio 1.5-2.00; near the base is the widest portion, narrowed toward the apex; the dorsal base cordate, inflated and arching across on the stem, the dorsal and ventraal base be found auricle, ventral base margins inflated, the dorsal and ventral margin undulate with minutely serrulate (projecting cell walls); the apex rounded with indistinctly tridentate, at the teeth with accessory minute denticulations (Figure 8.E), the teeth variable in size and shape, regularly acute, the anterior tooth 3-6 cells long, 4-7 cells wide, the median tooth 4-8 cells long, 8-13 cells wide, the posterior tooth 3-7 cells long, 4-9 cells wide, sinus mostly such as the letter $\mathrm{V}$; leaf cells elongate rectangular to isodiametric, 32.35-43.52 x 23.29-28.02 $\mu \mathrm{m}$ in the base, $34.25-41.95 \times 20.34-24.99 \mu \mathrm{m}$ in the middle, 27.54-35.77 $\mathrm{x}$ 18.93-25.63 $\mu \mathrm{m}$ near the apex, trigones large, 9.56-16.27 x 5.86-10.33 $\mu \mathrm{m}$, strongly nodulose, often confluent. Underleaf distant, transversely inserted; adaxially plane, sometimes reflexed at the apex (Figure 8B); broadly orbicular, 0.37-0.78 $\mathrm{mm}$ long (Figure 8D), 0.59-0.99 mm wide, long/wide ratio 0.7-1.1, larger from the stem, the basal cordate to auriculate, the margin subentire to emarginate, the apex obtuse to emarginate. Underleaf cells chlorophyllous, bordered by the hyaline 12 layer of cells (Figure 8.H). Microphyll at flagellae ovate, 178.31-200 $\mu \mathrm{m}$ long, 198-210.300 $\mu \mathrm{m}$ wide, base transversal, margin entire-serrulate, apex obtuse-serrulate (Figure 8.I)

Specimen examined: Indonesia: Java: Central Java: Mount Slamet (1219-1697 m asl.). September 2015. L. Khotimperwati. S2, S3, S4, S5, S11.

Distribution: Thailand, Malay Peninsula, Bangka, Sumatra, Java, Borneo (Meijer 1960; Kitagawa 1967; Soderstrom et al. 2010).

Note: B. spiralis is characterized by triangular-ovate leaves, margin serrulate, the teeth with accessory minute denticulations, broadly orbicular underleaves with cordate bases, the hyaline margin of one or two cells in width (Kitagawa 1967). B. spiralis can be confused with B. erosa. $B$. spiralis has characteristic in the shape and cell hyaline margin of underleaf with $B$. erosa, but it has distant underleaf and reflexed at the apical margin.

\section{Bazzania succulenta N. Kitag.}

Bazzania succulenta N.Kitag., J. Hattori Bot. Lab. 47: 141, 1980 (Kitagawa 1980). Figure 11.A-I.

Description: Plant green-brownish, robust, 3.41-4.17 $\mathrm{mm}$ wide, branching lateral pseudodichotomous, inclined to divergent at $64.25^{\circ}-79.38^{\circ}$. Stem ellipsoid in crosssection, about 16 thick cells, $0.40-0.5 \mathrm{~mm}$ across in diameter, stem circle 38 cells, merophyte ventrals 11-13 cells. Leaves opposite, incubous, obliquely inserted, overlapping on the median line of the stem, very imbricate, inclined at $69.1^{\circ}-80.6^{\circ}$ with the stem, very curved ventrally (Figure 11.A), asymmetrical, falcate, widely ovatetriangular (Figure 11.C); 2.14-2.46 mm long, 1.61-1.89 $\mathrm{mm}$ wide, long/wide ratio 1.26-1.53; narrowed toward the apices, the dorsal base cordate, inflated and arching across at the stem, the ventral base margins arched and in the midle there are constricting (Figure 11.B); at the ventral and dorsal base be found auricle (Figure 11.C-D); the dorsal and ventral margin of leaf serrulate with projecting cell-walls; the apex rounded, serrulate, not dentate (Figure 11.E); leaf-cells hexagonal-rectangular, 68.54-82.29 x $39.75-46.44 \mu \mathrm{m}$ in the base, $44.92-59.16 \times 22.84-27.83 \mu \mathrm{m}$ in the middle, 39.86-47.08 x 24.74-29.08 $\mu \mathrm{m}$ near the apex; trigones large 20.0-26.69 x 13.14-18.16 $\mu \mathrm{m}$, strongly nodulose and confluent. Underleaf contiguous-imbricata, inserted arched upward; adaxially convex, reflexed at the apex, very large, orbicular; 0.83-0.94 mm long, 1.25-1.34 $\mathrm{mm}$ wide, long/wide ratio 0.63-0.69, larger from the stem, the basal cordate, the margin emarginate, the apex obtuseemarginated; underleaf cells are mostly composed of chlorophyllous, on the apicals margin is composed of hyaline cells (Figure 11.G-H). Microphyll at flagellae ovate, 216.18-224.85 $\mu \mathrm{m}$ long, 170.17-173.13 $\mu \mathrm{m}$ wide; base transversal, margin serrulate, apex serrulate (Figure 11.I).

Specimen examined: Indonesia: Java: Central Java: Mt. Slamet (1330 m asl.) on terrestrial. September 2015. L. Khotimperwati. S6

Distribution: West New Guinea (1600 m asl.), epiphytic on the tree, Java (Central Java: new record).

Note: B. succulenta is a new record in Java. The plant looks like succulent because cells of leaf and underleaf are swollen, therefore succulent so that use as the specific epithet (Kitagawa 1980). The other characteristic of this species is the asymmetrically triangular-ovate leaf, there are no dentate in the apex, but only minutely serrulate; underleaf very large and concave abaxially.

\section{Bazzania tridens (Reinw., Blume et Nees) Trevis.}

Bazzania tridens (Reinw., Blume et Nees) Trevis., Mem. Reale Ist. Lombardo Sci. (Ser. 3), C. Sci. Mat. 4 (13): 415, 1877 (Trevisan 1877). Figure 12.A-H.

Synonym: Jungermannia tridens Reinw., Blume et Nees, Nova Acta Phys.-Med. Acad. Caes. Leop.-Carol. Nat. Cur. 12 (1): 228, 1824 [1825] (Reinwardt et al. 1824a). B. sinensis Gottsche ex Stephani, Hedwigia 25: 208, 1886. Mastigobryum sinensis (Steph.) Steph., Sp. Hepat. 3: 506, 1908. M. albicans Steph., Sp. Hepat.3: 465 (1908). B. albicans (Steph.) Horik., J. Sc. Hiroshima Univ. Ser.B.Div. 2,2:200, 1934. M. formosae Steph., Sp. Hepat. 3: 466, 1908. B. formosae (Steph.) Horik., J. Sc. Hiroshima Univ. Ser. B. Div. 2, 2: 196, 1934; Herz., mem. Soc. Fam. Fl. Fenn. 26: 44, 1951. 

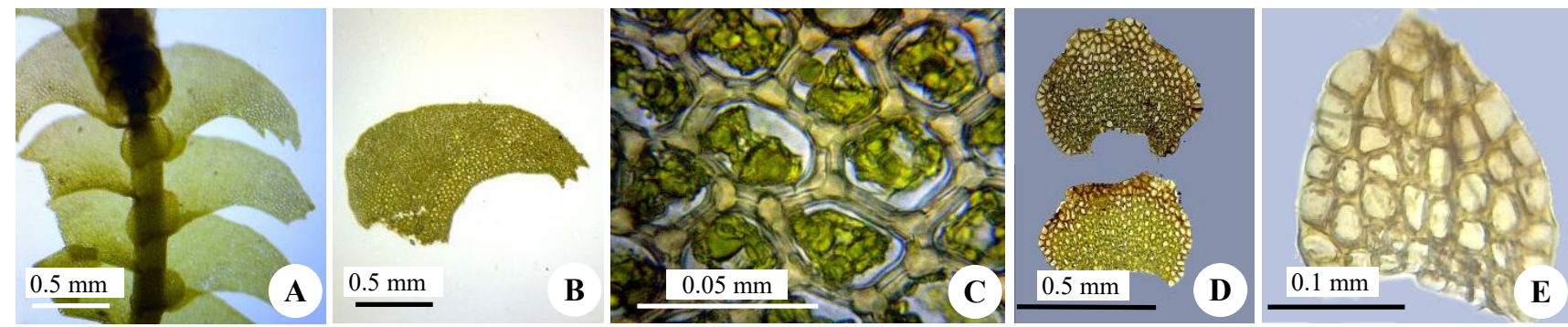

Figure 9. Bazzania serpentina, A. Thallus, B. Leaf, C. Leaf cells, D. Underleaf, E. Microphyll
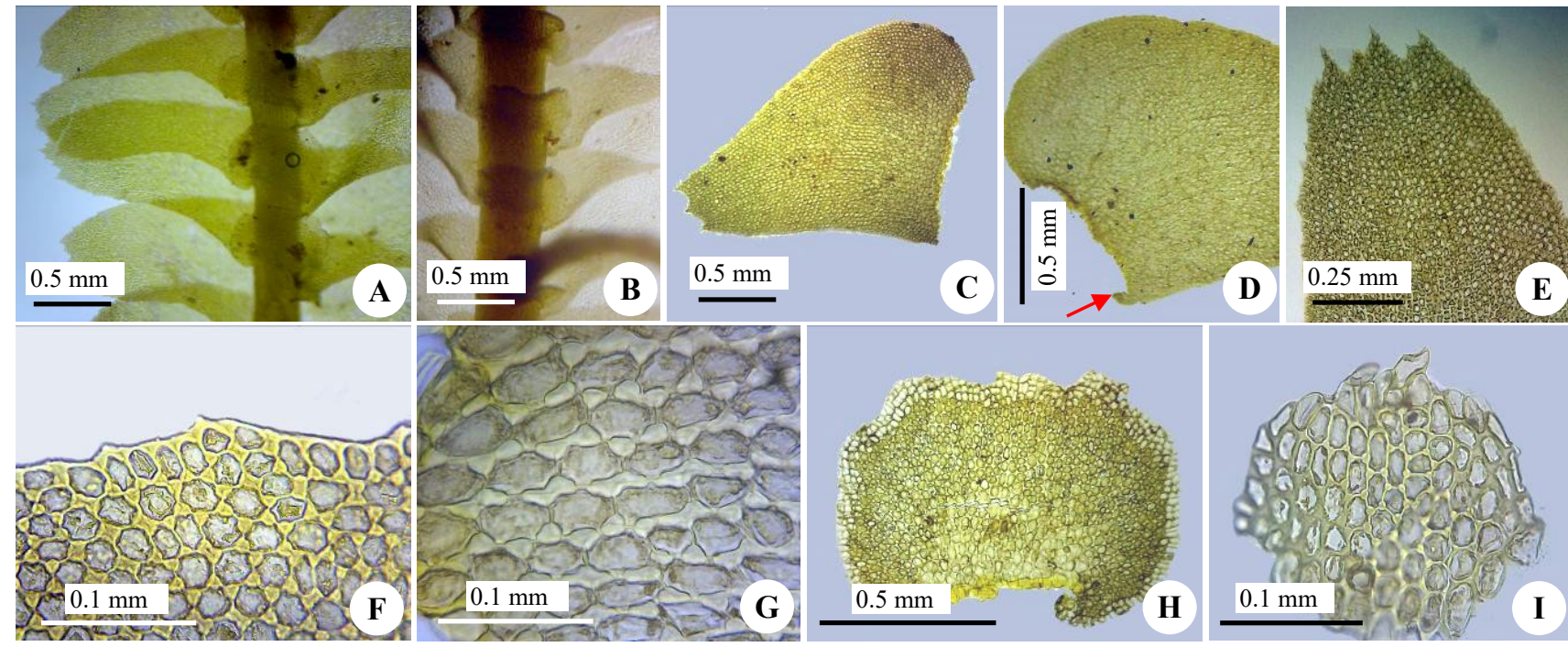

Figure 10. Bazzania spiralis: A. Thallus, B. Part of the thallus, C. Leaf, D. Leaf basal, E. Leaf apex, F. Dorsal margin, G. Leaf cells, H. Underleaf, I. Microphyll

Description: Plant yellowish-green, phylliform to robust, 2.84-3.46 $\mathrm{mm}$ wide; branching lateral pseudodichotomous, inclined to divergent at $77.47^{\circ}-92.85^{\circ}$. Stem ellipsoid in cross-section, about 12-14 thick cells, 0.22-0.29 mm across in diameter, stem circle 29-32 cells, merophyte ventrally 8-16 cells. Leaves distichously, incubous, dorsal insertion is straight at the stem, contiguous to loss imbricate, inclined to divergent at $58,7^{\circ}-86,3^{\circ}$ with the stem, asymmetrical, subfalcate, ovate-oblongs, 1.42$1.84 \mathrm{~mm}$ long, $0.52-0.89 \mathrm{~mm}$ wide, long/wide ratio 1.8-2.3; narrowed toward the apices, the dorsal base subcordatecordate, the ventral base rather cordate, the margin dorsal and ventral of leaf entire, the apex variable in form are truncate, rounded, acute, tridentate, sometimes bidentate, the teeth acute-acuminate, the anterior tooth 3-8 cells long, 3-9 cells wide, the median tooth 4-10 cells long, 4-9 cells wide, the posterior tooth 3-9 cells long, 3-7 cells wide, sinus between teeth lunulate to such as letter V; leaf-cells rectangular-quadrate (Figure 12.D), 34.43-43.46 x 19.02$29.50 \mu \mathrm{m}$ in the base, $27.75-45.59 \times 17.68-27.70 \mu \mathrm{m}$ in the middle, $18.23-25.24 \times 15.17-17.55 \mu \mathrm{m}$ near the apex, trigones medium, 4.5-8.37 x 2.9-5.75 $\mu \mathrm{m}$. Underleaf distant to contiguous, transversely inserted, appresed to the stem; the base usually connate with one side of the lateral leaf, variable in size and form, usually rectangular- quadrate-oblongs, $0.31-0.71 \mathrm{~mm}$ long, $0.38-0.78 \mathrm{~mm}$ wide, long/wide ratio $0.8-1.02$, larger from the stem, sometimes as wide as the stem, the basal straight, the margin repand, the apex truncate-emarginated-cornulate, with papilla; underleaf cells almost composed of hyaline cells, chlorophyllous cells only at the basal underleaf (Figure 12.E-F). Microphyll at flagellae triangular, 163.34-236.1 x 175.7-177.78 $\mu \mathrm{m}$, base transverse, margin emarginate, apex acute and toothed (Figure 12.G-H).

Specimen examined: Indonesia: Java: Central Java: Mt. Slamet (931 m asl.), Mt. Lawu (1910-2513 m asl.) and Mt.Ungaran (2040 m asl.) on terrestrial. September 2015. L. Khotimperwati.S1, U2, U5, L1, L5, L10, L11, L12.

Distribution: Java, Sumatra, Borneo, Moluccas (Meijer 1960; Soderstrom et al. 2010), S. India, W. Bengal, Assam, Sri Lanka, Nepal, Sikkim, Bhutan, Myanmar, Thailand, Celebes, Seram, China, Formosa, Japan, Korea (Kitagawa 1967; Mizutani 1967; Pocs 1969; Zhou et al. 2012).

Note: B. tridens is sometimes confused with $B$. pectinata, both are distinguished by leaves size, the structure of underleaf and trigones (described in $B$. pectinata). B. tridens also resembles $B$. vittata on form, margin, and cell underleaf, but $B$. tridens has 2-4 layers chlorophyllous cell on the basal, whereas $B$. vittata has underleaf cells that are hyaline. 


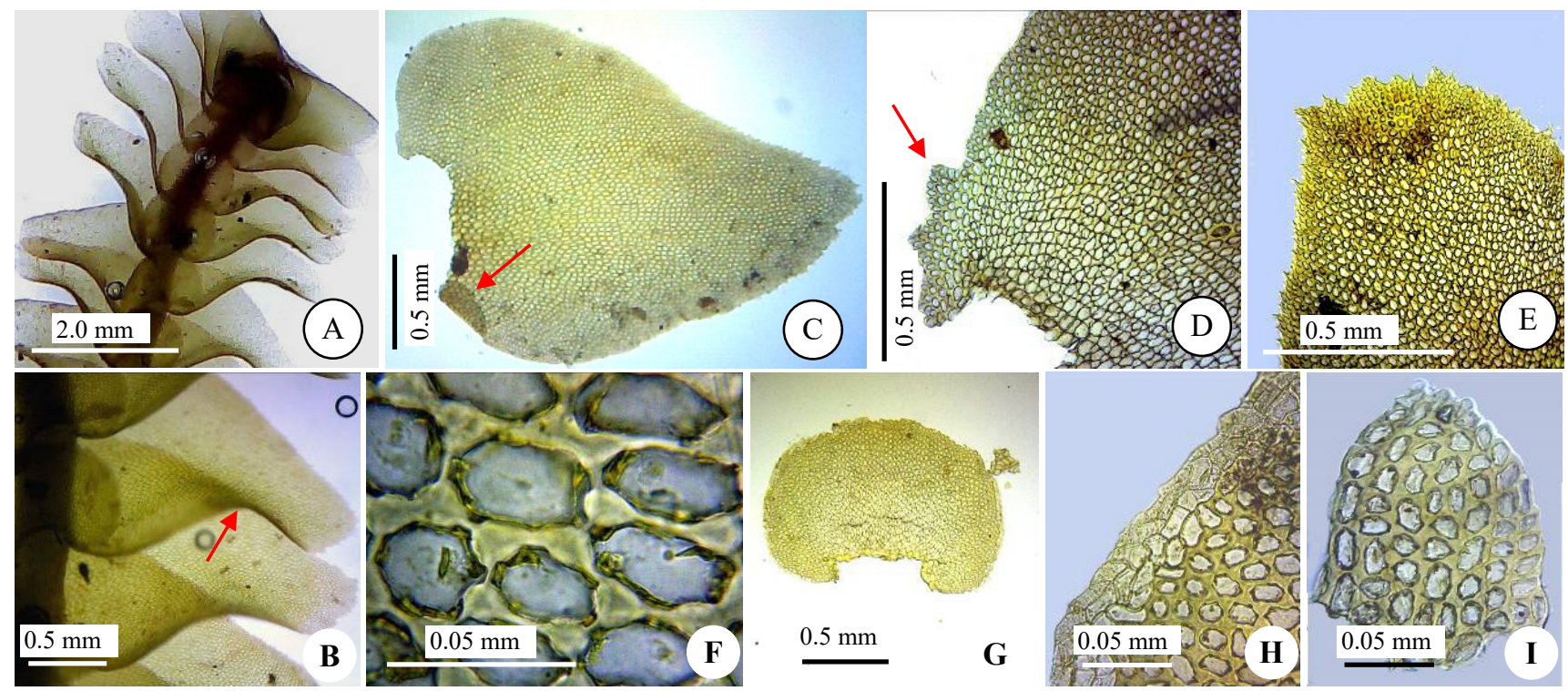

Figure 11. Bazzania succulenta: A. Thallus, B. Part of thallus, C. Leaf, D. Leaf basal, E. Leaf apex, F. Leaf cells, G. Underleaf, H. Underleaf margin, I. Microphyll
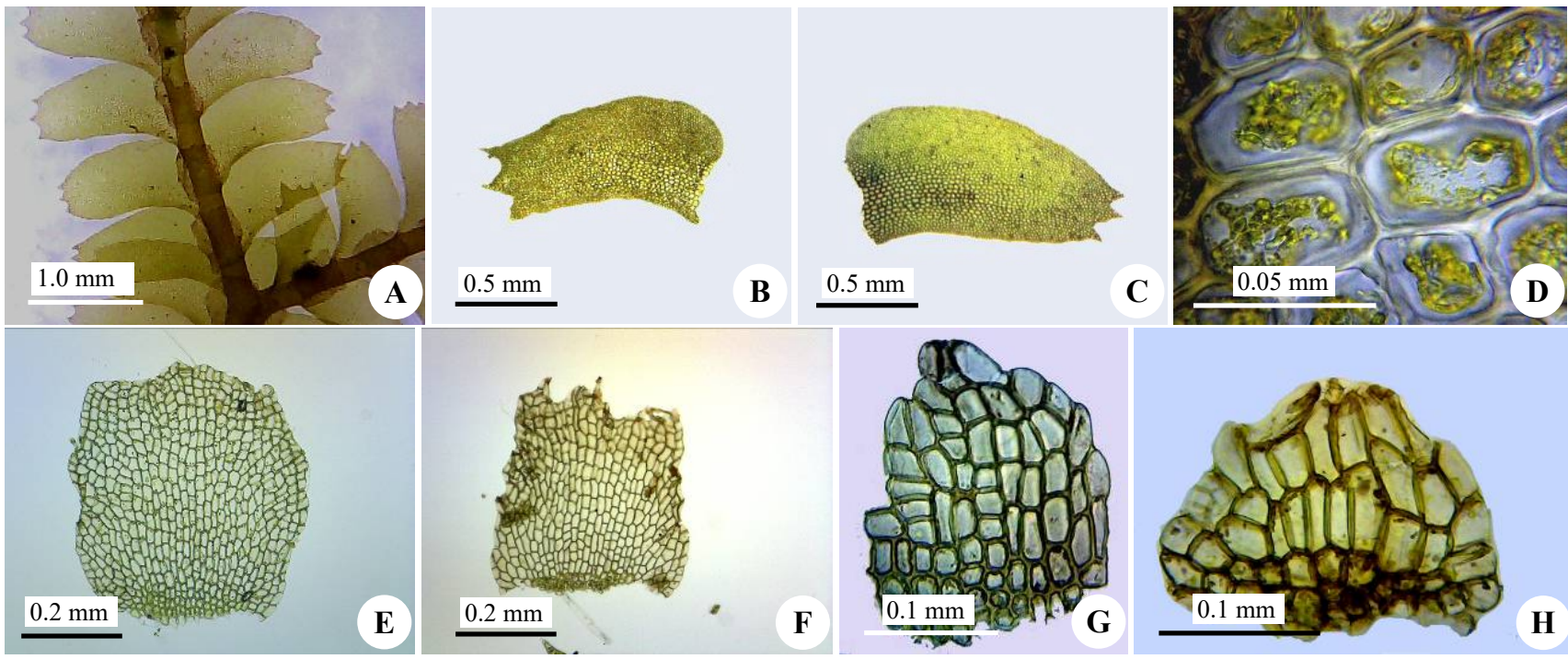

Figure 12. Bazzania tridens: A. Thallus, B-C. Leaf, D. Basal leaf cells, E-F. Underleaf, G-H. Microphyll

\section{ACKNOWLEDGEMENTS}

This research is part of a doctoral dissertation at the Biological Sciences Study Program, Faculty of Biology, Universitas Gadjah Mada, Yogyakarta, Indonesia and funded by BPPS Directorate General of Higher Education, Ministry of Education and Culture of the Republic Indonesia. This research also supported by PDD (Penelitian Disertasi Doktor) grant 2017, Ministry of Research, Technology and Higher Education of the Republic of Indonesia. The authors thank to Dr. Nunik Sri Ariyanti for discussion about the identification of Bazzania, and
Mr.Giusti Ghivarry for making the distribution map of Bazzania.

\section{REFERENCES}

Bakalin VA. 2016. A revision of Lepidoziaceae (Hepaticae) in the Russian Far East I. Bazzania. Botanica Pacifica (5) 1: 33-52.

Bernecker-Lucking A. 1999. Key to Latin American species of Bazzania S,F, Gray. Tropica Bryology 16: 117-126.

Cheah YH, Yong KT. 2016. New records of Bazzania species (Marchantiophyta: Lepidoziaceae) in Peninsular Malaysia with identification key. Cryptogamie Bryologie 37 (2): 199-210.

Evans AW. 1933. Some representative species of Bazzania from Sumatra. Pap Michigan Acad Sci Arts Lett 17: 69-118.

Gradstein SR, Churchill SP, Allen NS. 2001. Guide to the Bryophytes of Tropical America. New York Botanical Garden Press, New York. 
Gradstein SR, Tan BC, Zhu RL, Ho BC, King SCH, Drbert C, Pitopang R. 2005. A catalouge of the Bryophytes of Sulawesi, Indonesia. J Hattory Bot Lab 98: 213-257.

Gradstein SR. 2011. Guide to the Liverworts and Hornworts of Java. Seameo Biotrop, Bogor.

Gradstein SR. 2017. Bazzania (Marchantiophyta) in South America. Nova Hedwigia 105 (1-2): 243-266.

Hattori S, Mizutani M. 1958. A Revision of the Japanese Species of the Family Lepidoziaceae. J Hattory Bot Lab 19: 76-118.

Kitagawa N. 1967. Studies on The Hepaticae of Thailand. J Hattory Bot Lab 30: 249-270.

Kitagawa N. 1977. Studies on Asian species of Bazzania, Hepaticae I. Bull Nara Univ Educ 26: 73-82.

Kitagawa N. 1979. Studies on Asian species of Bazzania. Hepaticae II. Bull Nara Univ Educ 28: 71-83.

Kitagawa N. 1980. New Guinean species of the genus Bazzania I. J Hattory Bot Lab 47: 127-143.

Lestari RW, Ariyanti NS. 2017. Bazzania (Marchantiophyta: Lepidoziaceae) di Taman Nasional Gunung Leuser (Sumatra). Floribunda 5 (7): 227-238.

Long DG, Rubasinghe SCK. 2014. Liverworts and Hornworts of Sri Lanka: a revised checklist. Ceylon J Sci 43 (1): 1-36.

Luong TP Thien-Tam, Ho BC. 2013. New Little Known Epiphyllous Liverworts, XVIII. Records from The Bidoup-Núi Bà National Park, Vietnam, with the Description of Drepanolejeunea bidoupensis, sp. nov. Cryptogamie Bryologie 34 (3): 287-298.

Meagher D. 2015. Studies on Bazzania (Marchantiophyta: Lepidoziaceae) 8. Bazzania wooroonooran sp. nov. and seven other rare species from tropical Australia. Nova Hedwigia 100 (3-4): 535-552.

Meagher D. 2006. Bazzania scalaris sp. nov. (Marchantiophyta: Lepidoziaceae) from Papua New Guinea. Telopea 11 (3): 246-251.
Meijer W. 1960. Notes of the species of Bazzania (Hepaticae) mainly in Java. Blumea 10: 323-661.

Menzel M. 1988. Annotated catalogue of the Hepaticae and Anthocerotae of Borneo. J Hattory Bot Lab 65: 145-206.

Mizutani M, Chang KC. 1986. A Preliminary Study of Chinese Lepidoziaceae Flora. J Hattory Bot Lab 60: 419-437.

Mizutani M. 1967. Studies of The Himalayan Species of Bazzania. J Hattory Bot Lab 30: 7-90.

Petiot MSC. 2011. A Checklist of Hepaticae and Anthocerotae of Malaysia. Polish Bot J 56: 1-4.

Pócs T. 1969. A short survey of the Bazzania of North Vietnam. J Hattory Bot Lab 32: 81-94.

Sari NK. 2015. Keanekaragaman Bazzania di Hutan Sibayak Sumatra Utara. [Hon. Thesis]. Institut Pertanian Bogor, Bogor. [Indonesian].

Schiftner V. 1898. Consperctus Hepaticarum Archipelagi Indici. Staatsdruckerei, Batavia.

Shukkharak P, Kitlap P, Likananonn A, He S. 2014. A preliminary study of bryophytes in the Khao Soi Dao wildlife sanctuary, Chanthaburi Province, Thailand. Songklanakarin J Sci Technol 36 (5): 527-534.

So, ML. 1996. Mosses and Liverworts of Hong Kong. Heavenly People Depot, Hong Kong.

Soderstrom L, Gradstein SR, Harborg A. 2010. Checklist of the Hornworts and Liverworts of Java. Phytotaxa 9:53-149.

Steenis CGGJ van. 1972. The Mountain Flora of Java. E.J.Brill, Leiden.

Stephani F. 1909. Species Hepaticarum. Bulletin de L'Herber Boissier 3: 413-540.

Zhou L-P, LiZhang, Xing F-U. 2012. Taxonomical Review of Bazzania (Lepidoziaceae, Marchantiophyta) in China. J Fairylake Bot Gard 11 (2): $1-62$. 